\title{
Three shell types in Mardinella daviesi indicate the evolution of a paratrimorphic life cycle among late Paleocene soritid benthic foraminifera
}

Lorenzo Consorti, Felix Schlagintweit, and Koorosh Rashidi

Acta Palaeontologica Polonica 65 (3), 2020: 641-648 doi:https://doi.org/10.4202/app.00703.2019

Soritids are a successful group of larger Foraminifera with several extant representatives that display a complex alternation of generations, the so-called paratrimorphic life cycle. Fossil soritids are abundantly widespread through the geological record starting from the Albian. The oldest Soritidae possessing annular chambers and cross-wise oblique chamber communications is represented by the Paleocene species Mardinella daviesi. The present paper provides a description of the morphology and anatomy of the three reproductive generations recovered in a Mardinella-rich assemblage from a lower Paleogene shallow-water carbonate succession in SW Iran (Zagros Zone). Comparison among proportion of schizonts vs. gamonts with extant soritids shows that there is an easy match. This would confirm that the paratrimorphic life cycle was successfully adopted by the early soritids to maintain fitness with the environment and to keep a stable mutual relationship with a certain group of endosymbionts.

Key words: Foraminifera, Soritidae, reproduction cycle, endosymbionts, Paleogene, Iran.

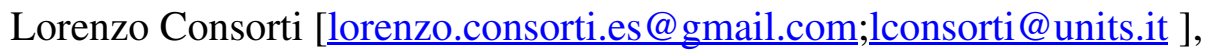
Department of Mathematics and Geosciences, University of Trieste. Via Weiss 2, Trieste, Italy. Felix Schlagintweit [felix.schlagintweit@gmx.de], Lerchenauerstr. 167, 80935 München, Germany. Koorosh Rashidi [kooroshrashidi@yazd.ac.ir], Department of Geology, Yazd University, 89195-741 Yazd, Iran.

This is an open-access article distributed under the terms of the Creative Commons Attribution License (for details please see creativecommons.org), which permits unrestricted use, distribution, and reproduction in any medium, provided the original author and source are credited. 
Fof 